\title{
The Maori and the Pakeha in C. K. Stead's Novel Talking About O'Dwyer
}

\author{
Igor Maver
}

\begin{abstract}
The article focuses on a recent novel by the contemporary New Zealand author C.K. Stead, Talking about O'Dwyer. It represents an indictment of war per se, war as a collective madness and its consequences for the life destinies of every single individual caught in it. The Second World War and the independence war in Croatia in the 1990s are minutely described and juxtaposed in this work: both brought to the people, as all wars, suffering and death and have radically changed and marked their lives and relationships. C.K. Stead writes about four locales in very different time periods, New Zealand, Oxford, and especially Croatia and Greece, where the two wars that affect the lives of the protagonists took place.
\end{abstract}

Keywords: C.K. Stead, New Zealand literature, war 
The first part of the title of this article deliberately points to the basic tension in New Zealand cultural and political history, i.e. the history of the Maori islands of Aotearoa (the country of the long white cloud)/New Zealand before the arrival of the colonizers, on the one hand, and the white-settler Pakeha tradition on the other, from the very beginning of the charting of New Zealand physically and spiritually for the Western imagination in 1769. It was, similarly to Australia, labelled terra australis incognita, the construct of the wildest Western-European projections of extreme exoticism of the early (pre)romantic bourgeoning just before the French Revolution, which is the merit of the legendary British explorer of the South Seas, Captain James Cook who 'discovered' Australia in 1770. His statues or grotesquely overdimensioned images in more or less precious materials can still today be found in several Australian and/or New Zealand museums, hotels or even the most dingy country inns: history can (sometimes) sell for profit. Just like its bigger neighbour Australia, New Zealand too has for a long time felt the 'tyranny of distance' (from the British colonial centre) and some sort of geographic schizophrenia. At the same time it was, nationally politically and culturally increasingly independent, caught in the love-hate relationship with the imperial English heart of Albion, which was being more and more exhausted by the decolonization processes all the way until the Second World War.

However, New Zealand has had a very different cultural and political development from its South Pacific great neighbour continent Australia. This is especially due to the indigenous Maori, caught in endless exhausting tribal struggles, who, nonetheless unified, signed with the English the Waitangi Treaty in 1840, which stipulated that they cede their sovereignty to the British in exchange for their protection but with an assured ownership of their lands. The British despite an implicit deceit still had to treat the Maori as equal interlocutors, which in contrast cannot be said for Australian Aborigines, whom the colonial authorities practically wanted to (and succeeded to) wipe out in certain parts of Australia. After many problems and tensions and a war between the Pakeha (the white people) and the Maori in the mid-nineteenth century, New Zealand first became a dominion within Great Britain and achieved its full independence only in 1947. During the recent years Maori culture and literature (Maoritanga) became strengthened, perhaps even more than the neighbouring Aboriginal one. The 1980s saw many new discords between the Maori and the Pakeha, since the New Zealand government tried to partly revise the Treaty of Waitangi with financial reparations to numerous Maori tribes whose lands were unjustifiably confiscated.

The past two decades have seen the rise of the literary imagination of the 'New' Pacific and thus of the indigenous production in English over the entire South Pacific and Oceania (apart from New Zealand e.g. also from Samoa, Fiji, Hawai'i, the Solomon Islands, the Cook Islands and Papua New Guinea). The 'New' Pacific 
literary-cultural body in the making is, as authors claim, traditionally a tattooed body and represents a combination (and certainly not a kind of transcultural hybrid) of the original indigenous Pacific tradition and mythology in their culturally almost completely absorbed English, which after Edward Said deconstructs and demystifies the construed Euro-American stereotypes of the 'Orient', in this instance Pacific culture. Authors that have made it internationally with their writings are, for example, Patricia Grace, Alan Duff, Albert Wendt, Witi Ihimaera, Keri Hulme, Marjorie Crocombe, Vilsoni Hereniko, Subramani, Epeli Hau'ofa, Haunani-Kay Trask and others. Many of these are actually from New Zealand, which in this geographical milieu a sort of cultural superpower, especially as regards the development of the new Pacific indigenous literary creativity (Hereniko).

The first major, internationally acclaimed literary author (many of whom were women) from New Zealand was Katherine Mansfield, who managed to break through the physical and spiritual borders of her homeland and the prejudice against the colonial women of her day. She was active in the London modernist Bloomsbury group scene (Virginia Woolf, D.H. Lawrence and others), who in the period between the two world wars far away from her constrictive New Zealand colonial context published the famous short story collections Bliss and Other Stories (1920) and The Garden Party and Other Stories (1922) and whose creativity was interrupted by her untimely death. Today the best known author from New Zealand is probably Janet Frame (1924-2004), who with her novels brought into New Zealand writing a whole new dimension: To the Is-Land (1983), An Angel at My Table (1984), The Envoy from Mirror City (1985), Carpathians (1988). A film based on her autobiographical trilogy An Angel at My Table (1990) resulted in the breakthrough of New Zealand film internationally, as well as the woman film-director Jane Campion, later on famous for her in-depth visual depictions of not understood and suppressed women especially in the colonial/Victorian milieu (e.g. the film The Piano and The Portrait of a Lady).

C. K. (Christian Karlson) Stead (b. 1932) became a well-known New Zealand writer only after his withdrawal from critical and academic life, which had been extremely productive and successful indeed. After his poetry beginnings in the 1950s he became a professor of literature at the University of Auckland and the author of a very well-received study of English poetic modernism (The New Poetic, 1964). In his academic career Stead dedicated much of his research time to the short story genre and particularly that of Katherine Mansfield. Since the 1980s he has been retired but during this time he has also established himself as a well-known New Zealand author of fiction: e.g. All Visitors Ashore (1984), The Death of the Body (1986), Sister Hollywood (1989), The Singing Whakapapa (1994), The End of the Century at the End of the World (1992, rpt. 1999). His recent book Mansfield (2004), a fictional biography of the writer Katherine Mansfield, was 
shortlisted for several literary prizes, including the Commonwealth Writers'Prize. C. K. Stead's fiction from his mature period is on the one hand very personal, while on the other he has also been labelled a metafictional author, for his books always reflect their own fictional status and the process of the genesis of the narrative. Such are, for instance, the movement between parallel narrative levels, set in the present and the past, the usage of supposedly 'original' documents writen by the protagonists, often the characters discuss the very process of writing the novel. On the other hand, Stead's novels are very lucid and straightforward, written in a realist manner, confessional even, with clear plots, although poetic passages and philosophical intellectual elements in them are plentiful as well (cf. Robinson).

One of the several narrative levels of the novel Talking about O'Dwyer (1999) refers to the period during the Second World War, when Donovan O'Dwyer as a Pakeha - a white New Zealander and commanding officer in the so-called 'Maori' batallion of the New Zealand division, in the fight for the Maleme airport during the battle for Crete between the English and the Germans, loses one of his men: the Maori Joe Panapa dies in unclear circumstances, which as a consequence causes his family, through aunt Pixie to pronounce a curse over O'Dwyer, a makutu. When he dies fity years later as a professor, a don, at Oxford University, his colleague and compatriot from New Zealand in Oxford, Mike Newall, is the only one that knows the whole story about O'Dwyer and this tragic event. Following a curious set of circumstances it also becomes his own, connected with his memories of youth, which decisively start to influence his present.

Stead masterfully intertwines these two stories in different time frameworks and the reader is confronted with a mosaic and something of a whodunit thriller operating through talking about O'Dwyer between Newall and his older Oxford colleague and friend Bertie Winterstoke over lunches in the local pub, while the complete truth is revealed only after O'Dwyer's funeral. Was O'Dwyer really responsible for the death of the Maori private Joe Panapa? This is what Newall was asking himself throughout his whole life, which is why he at all costs tried to reconstruct the story of Panapa's death, from letters, a diary, and most of all from the events and talk about his own life, which the author interestingly puts into the third person narrative. Newall, too, was a New Zealand expatriate in England, where he met his compatriot O'Dwyer, whom he had always admired and who also helped him in his professional advancement in Oxford. The migrant or rather the expatriate perspective is an important aspect of the novel, which is true of quite a few Australian and New Zealand literary works. Also, the larger context of talking between Oxford dons about O'Dwyer is somewhat reminiscent of the Anglo-American tradition of the so-called campus novel.

Mike Newall's best friend and next-door neighbour of his youth in New Zealand was Frano Panapa and he was the son of the very Maori soldier Joe Panapa 
killed in the war. Frano was the son of Joe and in the marriage with the Croatian migrant Ljuba Selenich, with whom also Frano's cousin Marica was living at the time. Mike was spending carefree years of youth with Frano that are realistically described from the point of view of the New Zealand way of life, 'New Zealand dream', and the atmosphere of relative intercultural and inter-racial tolerance and co-existence between the Maori, migrants from Europe and New Zealanders of Anglo-Celtic descent in the late forties and fifties of the previous century.

There was also the barrier of language. The younger Dalmatian adults, recently arrived, struggled with English; their parents spoke it hardly at all. And though the children were fluent in their language, they went to the local Catholic school, while the Newalls went to the State school, Henderson Primary. The two school groups, when their paths crossed, sometimes shouted juvenile insults back and forth. At those times the Newall and Selenich children behaved as if they didn't know one another. But on their home territories, which lay side by side, or back to back, divided only by a sagging wire fence, it would have needed a parental embargo to prevent fraternisation. There was no embargo. They played together, wandered in and out of one another's houses, were invited to one another's birthday parties, argued, as they grew older, about Papal infallibility and transubstatiation, and became part each of the other's lives and landscape. (17)

However, the love that bursts out between Mike and Marica put an end to the sweet dreams of youth: Frano is not able to accept this fact and dies in a car crash just after the revelation of their love. He may have even committed suicide, which the author does not explicitly confirm, nor deny. Mike's relationship with Marica is severed and he is quite shocked and sad.

The day after the death Mike walked all the way to Bridge Avenue, and sat where he and Frano had gone so often to swim. As he walked down Te Atatu Road, and as he sat alone watching the tide flow into the estuary, he was saying the word "dead" silently to himself, over and over, slowly, like a funeral march. Sometimes it took on its full painful meaning, at other times it became only a sound, an utterance, from which meaning vanished. (89)

Life then takes him, as a New Zealander, to the Vietnam war and, as he is an expert in the philosophy of Ludwig Wittgenstein, to advance his academic career in the United States of America. Then he moves to Oxford and becomes estranged form his wife Gillian, whom he painfully divorces, although they remain in close contact. This is one of the important narrative levels of the novel about Mike's intimate private life, interspersed with memories of the love of his youth Marica Selenich and the new, much younger woman he falls in love with in Croatia, Ira, while searching for answers about O'Dwyer and Marica. Mike Newall, professor 
of philosophy at Oxford is after years of 'talking about' O'Dwyer with his friend Winterstoke eventually brought to Croatia (Zagreb and Dalmatia), which was in the 1990s at war and in the process of gaining independence from Yugslavia that was falling apart. During his visit he becomes intimately close with Ira and makes contact with Ljuba, the widow of the Maori private Joe Panapa. She had in the meantime moved back to Dalmatia from New Zealand and in the search for her he once again encounters his long-lost love from his youth, Marica Selenich.

Mike explains. "Stella - my sister in New Zealand - she's still friends with the Selenich family. She phoned me. Ljuba Panapa - Frano's mother - had gone back to live in Croatia. She'd been there quite a few years, resettled in Dalmatia, in the area the family came from. But now trouble was looming. Slovenia and Croatia declared independence. Belgrade was threatening. Ljuba was in a disputed area. The family heard from a relative in Zagreb that her house had been damaged in a bombardment - or possibly destroyed, they weren't sure. They were worried. My sister wanted to know whether I had any way of finding out what had happened. They put the idea into my head. I'd visit Croatia before going to New Zealand. I'd be the one bringing out news. Mainly of course for Marica. She was always close to her aunt." (29)

On his deathbed Donovan O'Dwyer had asked Mike to scatter his ashes over Panapa's grave at Crete in Greece. Only towards the end of the book, in examining the causes, consequences and 'evidence' as in a detective story, do we learn that O'Dwyer shot Panapa, mortally wounded, in the head, to prevent him from falling into German hands (they were successfully occupying the Maleme airport); this is what Joe had been begging him to do. The curse, makutu, of Panapa's family over O'Dwyer had been pronounced precisely because of this shooting, which was in their view unnecessary and cruel, since they did not know the other circumstances of the death until the very death of O'Dwyer, who bore the curse stoically throughout his life and did not want to upset them any more.

Stead's descriptions of Zagreb during the war of independence, Dalmatia, Oxford university life, New Zealand or the US immediately after the Second World war, the events at Crete in Maleme and Chania are direct, suggestive, at times subtly poetic and without unnecessary pathos. They enable a constant tension, evocation of the memories of youth and the past, provide an insight into numerous relationships, friendly, love, family, inter-generational, inter-racial, inter-national and represent a short but very powerfully expressive vignette of war(s), serving not merely as the backdrop but as a veritable 'character' in the lives of the protagonists.

Zagreb itself was a strange mix, half imperial grandeur, half communist austerity. Its central streets and squares, its equestrian and literary statues, its museums 
and public buildings, elegant in the style of Vienna, generous in space, redolent of privilege, told one story; its broken pavements, dingy offices, and post-Second World War apartment buildings, grey and dirty and in need of every kind of repair, told another. The foreignness of the place, and the political and military drama of the moment, took him out of himself. He found himself interested, and not unhappy. But there were moments when he plunged back into the old wretchedness. Once, in a post-office with a notice which said ZABRANJENO UNOSITI ORUZJE, and showed, like a "no smoking", or "no dogs" sign, a handgun in a red circle with a diagonal red line through it, he was suddenly invaded by thoughts of Gillian, their house in North Oxford, the little lopsided gate and the copper beech at the front, the lovely walled garden with its apple trees at the back, and was embarassed by a tightening throat and prickling eyes. (33)

When he and Ira travel down to Dalmatia, he is shocked to see the disastrous effects of the war:

So he made his way down the road slowly, watchfully. Soon he was photographing the scene, the burned-out houses, feeling that it was faintly indecent, that he was a trespasser, but doing it anyway.

It was very quiet. There was no traffic on the road, no one among the ruins. The crops were running to seed. There were no animals grazing the pastures. He saw a black dog, all ribcage and backbone and hangdog head, scavenging in a grassy ditch. He whistled to it and held out his hand, but it loped off on three legs among rows of corn that were drying out unharvested. He could hear birds, a breath of wind among the trees, a river rustling under a bridge. The peace that followed war, it seemed, was more peaceful than the peace of human occupation. Nature raised no objection to ethnic cleansing. (193)

Stead's tolerant stance towards the Maori in the novel is certainly laudable and they are never exoticised. He does use quite a few Maori words in the text but adds a brief »Glossary of Maori Words for non New Zealand Readers« (145-6). The ending of C. K. Stead's novel Talking about O'Dwyer, however, is somewhat contrived: it takes place in Chania at Crete, where the author brings together all the living protagonists of the book, who are all connected in one way or the other, mostly as adversaries bearing various grudges against each other, and stages some kind of reconciliation ritual on the grave of Joe Panapa in the military graveyard with numerous New Zealand buried soldiers from World War Two:

39492 Private

J. P. PANAPA

N. Z. Infantry

24 May 1941 Aged 29 years 
It is not a coincidence that Stead at the beginning and at the end of the book uses a quote from the Roman poet Catullus that speaks about the return across many lands and seas, a farewell of the dead soldier and paying tribute to his memory. The Panapa family asks Marica Selenich to perform a karakia over the grave and thus lift the curse/makutu on the now deceased Donovan O'Dwyer. All of them gathered there seemingly bury their past grudges and anger, they reconcile with each other, adversaries in love and during the war, for they are now all 'Europeans'.

So Mike signals and the others make their way down to the grave. They range themselves around in a half-circle facing the headstone, backs to the sea, and Marica chants the karakia she has memorised. It's not a Maori voice - loud, harsh, like something torn from her in pain. It's not even (Mike thinks, remembering Ljuba's long-ago wailing and the recent cries of the young woman in the Dalmatian cemetery) a Croatian voice. It's an incantation, but the note is quiet, clear. He's moved by its reticence. Through his own mind are running the lines of the Catullus graveside poem - Multas per gentes et multa per aequora uectus / aduenio has miseras, frater, ad inferias - Across lands and seas I've come, brother, to take of you this last leave. (236)

It is true that some contemporary New Zealand literature is the prisoner of national, also war myths and symbols from the past, important for national identification. In this regard the battle of Maleme on Crete in Greece is somewhat reminiscent of the Australian war myth and the national holiday celebration of the ANZAC Day and its numerous literary and cultural (re)interpretations, the battle of Gallipoli in Asia Minor during the Great War on 25 April, 1915. However, a good writer must be able to go beyond collective symbols of this kind. Stead succeeds in doing just that, despite the too glamourous ending. He produces an effective mixture of action, detective story, romance, philosophical novel. Philosophical questions are addressed through Mike Newall's expertise on Wittgenstein, where he sometimes implicity makes fun of the British institutions: in a chapter entitled "Dog Save the King" he punningly muses that the word God can actually be read backwards and thus the word dog emerges. His hesitation and actions not taken are echoed in the chapter titled "Hamlet is My Middle Name" and the chapter "Is it I, God, or Who, that Lifts this Arm?", taken from Herman Melville's novel Moby Dick, where Captain Ahab poses himself this ontological rhetorical question. The novel is particularly important as an indictment of war per se, as a collective madness and its consequences for the life destinies of every single individual caught in it. The Second World War and the independence war in Croatia in the 1990s are minutely described and juxtaposed: both brought to the people, as all wars, suffering and death and have radically changed and marked 
their lives and relationships. C.K. Stead suggestively writes about four locales in very different time periods, New Zealand, Oxford, Croatia, and Greece. His freedom of moving from one to the other, back and forth in time, shows that the wars have really always been global, just as an unbearable lightness of freedom has always characterized the writer's imagination.

\section{WORKS CITED}

Hereniko, Vilsoni; Rob Wilson; Patricia Grace; David Hanlon, eds. Inside Out: Literature, Cultural Politics, and Identity in the New Pacific. Lanham, MD: Rowman \& Littlefield, 1999.

Robinson, Roger (ed.) and Nelson Wattie. The Oxford Companion to New Zealand Literature. Melbourne: Oxford UP, 1998. 512-514.

Stead, C. K. Talking about O'Dwyer. London: Random House, 2003.

Igor Maver University of Ljubljana, Slovenia Igor.Maver@ff.uni-lj.si

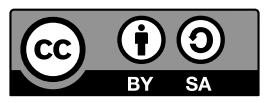

\section{Maori in Pakeha v romanu C. K. Steada talking about O'Dwyer}

Članek se osredinja na novejši roman sodobnega novozelandskega avtorja C.K. Steada, Talking about O'Dwyer. Ta predstavlja obsodbo vojne per se, vojne kot kolektivne blaznosti in njenih posledic za življenjsko usodo vsakega posameznika ujetega v njej. Druga svetovna vojna in vojna za neodvisnost Hrvaške v devetdesetih letih prejšnjega stoletja sta $\mathrm{v}$ tem romanu podrobno opisani in primerjalno obravnavani: obe prineseta protagonistom, kot vse vojne, trpljenje in smrt in radikalno spremenijo njihova življenja in medosebne odnose. C. K. Stead sugestivno opisuje štiri lokacije v različnih časovnih obdobjih, v Novi Zelandiji, Oxfordu in posebej na hrvaškem in v Grčiji, kjer se odvijata dve vojni, ki močno spremenita življenja ljudi.

Ključne besede: C. K. Stead, književnost Nove Zelandije, vojna 